\title{
Preface: Extreme Hydrological Events
}

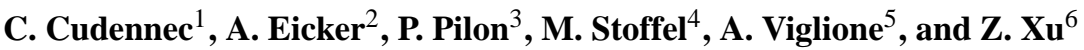 \\ ${ }^{1}$ Agrocampus Ouest, Rennes, France \\ ${ }^{2}$ Institute of Geodesy and Geoinformation, Bonn, Germany \\ ${ }^{3}$ World Meteorological Organization, Geneva, Switzerland \\ ${ }^{4}$ University of Geneva, Geneva, Switzerland \\ ${ }^{5}$ Vienna University of Technology, Vienna, Austria \\ ${ }^{6}$ Beijing Normal University, Beijing, China
}

Correspondence to: C. Cudennec (cudennec@ agrocampus-ouest.fr)

The security of Mankind is multi-faceted as it is challenged by many hazards and threats, with variable exposures across space and time. It is now recognized that the impacts of disasters are increasing (see, for example, WMONo. 1123, WMO, 2014) as is their complexity in many parts of the world, resulting in the Sendai Declaration "to enhance our efforts to strengthen disaster risk reduction to reduce losses of lives and assets from disasters worldwide" (UNGA, 2015, p. 1), with an emphasis on the role of Science (Aitsi-Selmi et al., 2015). Geophysical extreme events and geopolitical crisis have always been the two major causes of disasters and catastrophes. However, the risks are growing consistently with the acceleration and increasing complexity of the Anthropocene and through the emergence of new natural-technological interfaces and interactions, new cascading events and processes, severe changes in the drivers and internal features of (sub) systems, changing geographical vulnerability and resilience characteristics, and new hazards aside from the traditional ones.

The eight associations of IUGG - the International Union of Geodesy and Geophysics - develop scientific knowledge and methods concerning all geophysical processes that pose risk to society. In addition, IUGG also facilitates multidisciplinary approaches thanks to the richness of its communities and to catalyzing mechanisms (Ismail-Zadeh et al., 2014). One of these approaches is the establishment of bridging symposia during Union assemblies. At the 2015 Prague Assembly, the Union symposium U2 offered a panorama of keynotes on "Integrated disaster risk science - Accounting for extremes" from each of the Associations and ad hoc commissions. A major follow up event was the JH1 interassociations symposium dedicated to "Extreme hydrological events" as water is at the interface of several compartments and processes studied by the different disciplines. The JH1 symposium was organized in cooperation with WMO, with this PIAHS volume being a significant output.

Extreme hydrological events develop at the Earth's surface with low frequency and high magnitude. They are often driven by closely connected causal forces from other aspects of geophysics, such as meteorological, oceanographic, and seismological processes. They are often complex in terms of their distribution of water over time and space, its phases, and its impacts on storages. They also often develop over the interfaces of liquid freshwater with marine, atmospheric, icy and snowy solid, and ground waters. A large influence of such events also exists with human and physical geographies, in terms of feedback and feedforward process interactions, particularly in the areas of disaster risk management, disaster mitigation and prevention.

Consistent with the IAHS Panta Rhei initiative (Montanari et al., 2013) and the multi-dimensional definition of Water Security (Cudennec et al., 2015), this volume contains contributions on

- the assessment, measurement, understanding, modelling, forecasting, prediction and management of extreme hydrological events;

- the complexity of geophysical interfaces and sciencesociety interactions;

- new direct and indirect technologies, from specific observational techniques to modelling and statistical approaches;

- the challenges that these issues pose in the context of climatic, geographical and societal change; and

- conceptual advances regarding the concepts of the Anthropocene and the dimensions of Water Security. 


\section{References}

Aitsi-Selmi, A., Blanchard, K., Al-Khudhairy, D., Ammann, W., Basabe, P., Johnston, D., Ogallo, L., Onishi, T., Renn, O., Revi, A., Roth, C., Peijun, S., Schneider, J., Wenger, D., and Murray, V.: UNISDR STAG 2015 Report: Science is used for disaster risk reduction, http://preventionweb.net/go/42848, last access: 1 June 2015.

Cudennec, C., Demuth, S., Mishra, A., and Young, G.: Hydrological sciences and water security: Past, present and future, PIAHS, vol. 366, http://www.proc-iahs.net/366/index.html, last access: 1 June 2015.

Ismail-Zadeh, A., Urrutia-Fucugauchi, J., Kijko, A., Takeuchi, K., and Zaliapin, I.: Extreme natural hazards, disaster risks and societal implications, Special Publications of the IUGG, Cambridge University Press, 2014.
Montanari, A., Young, G., Savenije, H., Hughes, D., Wagener, T., Ren, L., Koutsoyiannis, D., Cudennec, C., Grimaldi, S., Blöschl, G., Sivapalan, M., Beven, K., Gupta, H., Arheimer, B., Huang, Y., Schumann, A., Post, D., Taniguchi, M., Boegh, E., Hubert, P., Harman, C., Thompson, S., Rogger, M., Hipsey, M., Toth, E., Viglione, A., Di Baldassarre, G., Schaefli, B., McMillan, H., Schymanski, S., Characklis, G., Yu, B., Pang, Z., and Belyaev, V., 2013: "Panta Rhei - Everything Flows": Change in hydrology and society - The IAHS Scientific Decade 2013-2022, Hydrolog. Sci. J., 58, 1256-1275, doi:10.1080/02626667.2013.809088, 2013.

UNGA: A/69/L.67, Sendai framework for disaster risk reduction 2015-2030, 15 May 2015, http://www.preventionweb.net/files/ resolutions/N1514318.pdf, last access: 1 June 2015.

WMO: Atlas of mortality and economic losses from weather, climate and water extremes (1979-2012), WMO-No. 1123, Geneva, Switzerland, 2014. 